\title{
GÉNESIS Y POÉTICA DE LOS MICRORRELATOS DE ANTONIO PEREIRA
}

GENESIS AND POETICS OF ANTONIO PEREIRA'S SHORT SHORT STORIES

Ana Calvo Revilla

Universidad CEU San Pablo

crevilla.ihum@ceu.es

Recibido: 06.04.2020

Aceptado: 30.01 .2021

RESUMEN: En este artículo analizamos los microrrelatos de Antonio Pereira, escritor que forja su vocación a la brevedad en su obra poética y en el periodismo. Sin sujetarse a las normas canónicas y a la cuestión genérica, el escritor rompe los límites establecidos y llega al microrrelato a través de la condensación de los componentes no narrativos y descriptivos del poema en prosa. Dentro de la narrativa breve este género literario representa una mínima parte en su obra literaria y está diseminado entre sus libros de cuentos: Picassos en el desván (1991), Los brazos de la i griega (1982), Relatos sin fronteras (1998), Cuentos de la Cábila (2000) La divisa en la torre (2007). Estudiamos la génesis de sus microrrelatos y la procedencia de algunas historias que configuran sus tramas, como algunas noticias leídas en la prensa con el fin de profundizar en el proceso de condensación narrativa al que Pereira somete la trama a través de la elipsis a una continua poda, que está al servicio del rigor de la composición y de la palabra exacta. Definimos los rasgos configuradores del estilo de Pereira en la escritura de microrrelatos, como el autobiografismo, las reflexiones metaficcionales, el registro oral, el culturalismo, la condensación de la anécdota, el juego con la hibridación genérica, la depuración del erotismo y los cambios de perspectiva; y perfilamos los recursos a través de los cuales el escritor subvierte los campos semánticos y desestabiliza el orden previsto, como la condensación lírica, el humor, la ironía, los juegos lingüísticos y la paradoja, entre otros.

PALABRAS ClaVe: Antonio Pereira, microrrelato, metaficción, humor, erotismo

ABSTRACT: In this article we analyze the short short stories of Antonio Pereira, a writer who forges his vocation to the brevity in his poetic work and in journalism. 
Without subjecting himself to the canonical norms and the generic question, the writer breaks the established limits and arrives at the micro-story through the condensation of the non-narrative and descriptive components of the prose poem. Within the short narrative this literary genre represents a minimal part in his literary work and is scattered among his books of short stories: Los brazos de la i griega (1982), Picassos en el desván (1991), Relatos sin fronteras (1998), Cuentos de la Cábila (2000) y La divisa en la torre (2007). We study the genesis of his short short stories and the origin of some of the stories that make up his plots, such as some news read in the press in order to deepen in the process of narrative condensation to which Pereira submits the plot through ellipsis to a continuous pruning, which is at the service of the rigor of the composition and the exact word. We define the features that shape Pereira's style in the writing of short short stories, such as autobiography, metafictional reflections, oral register, culturalism, condensation of the anecdote, the play with generic hybridization, the purification of eroticism and changes of perspective; and we outline the resources through which the writer subverts semantic fields and destabilizes the expected order, such as lyrical condensation, humor, irony, linguistic games and paradox, among others.

KEYWORDS: Antonio Pereira, short short story, metafiction, humor, eroticism

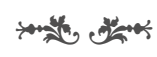

\section{EN EL DESVÁN DE LA BREVEDAD}

Antonio Pereira (1923-2009) es un escritor español que no precisa presentación. Su compromiso con la literatura ha sido, aunque no excluyente, sí total. Aunque pudiera parecer que su llegada a la literatura fue por la puerta de atrás, como se dijo del gran Chéjov (San Vicente 2018: 475), literatura y vida permanecen estrechamente unidas en su producción literaria. No sabe el escritor vivir sin animar y enriquecer la experiencia cotidiana con la savia de las letras, como constata en una anotación diarística en Oficio de mirar, fechada en el mes de abril de 1970: "Me cuesta trabajo desenganchar de mi literatura y ponerme a cumplir con mi otra vida, aunque no creo que con ello se perjudiquen mis versos y mis prosas tanto como algunos creen" (Pereira 2019: 19).

Pereira es maestro del escribir corto, de la brevedad, de la sencillez y de los movimientos sutiles del alma humana. La extrema concisión y la claridad son rasgos sobresalientes de su obra literaria. Por encima de las normas canónicas y de la cuestión genérica, la poética pereiriana rompe los límites establecidos y fragmenta el tiempo y el espacio narrativos para expresar lo inexpresable, que solo él cuenta de manera personalísima. La brevedad no es una simple, sino un 
instrumento al servicio de la historia que quiere contar para hacer sentir y transmitir al lector con humor e ironía su visión de la vida.

¿Dónde creció su vocación a la brevedad? Podríamos hablar de dos cauces fundamentalmente: la poesía y el periodismo. Se forjó desde la adolescencia entre unos sencillos desvanes repletos de libros que suscitaron sus primeros atrevimientos con las letras. Durante sus estudios de bachillerato y de la mano de sus maestros don Manuel Santín y don Antonio Carvajal Álvarez de Toledo, el joven de Villafranca del Bierzo se inició con la escritura del primer poema. Sin embargo, no fue hasta la década de los cuarenta cuando la hospitalidad de los poetas de la revista leonesa Espadaña (Victoriano Crémer, Eugenio de Nora, Luis López Anglada, José Castro Ovejero) y de su bibliotecario Antonio González de Lama le permitieron desplegar su vocación a la poesía y retomar los cauces humanistas de Claraboya (1963-1968), donde publicó varios poemas. En el desván de la poesía, de estas y otras revistas, como Alba, Caracola o Ínsula, nacieron los libros de poemas El regreso (1964), Del monte y los caminos (1966), Cancionero de Sagres (1969) y Dibujo de figura (1972). Ahí brotó también el cauce narrativo de los primeros cuentos: "Cuento de Navidad", en Diario de León, en 1957 y "Algo así como la crápula", que vio la luz en La Estafeta Literaria, en 1965. Y en esta fuente nacieron también Una ventana a la carretera (1967), primer libro de cuentos que publicó con el estímulo de Ramón Carnicer y con el que ganó el premio Leopoldo Alas ${ }^{1}$ y los que le sucedieron en las décadas de los 60 y 80: El ingeniero de Balboa y otras historias civiles (1976), Historias veniales de amor (1978), Los brazos de la i griega (1982), El síndrome de Estocolmo (1988), por el que mereció el Premio Fastenrath de la RAE y Cuentos para lectores cómplices (1989).

Aunque el escritor proclamó en diversas ocasiones que le hubiera gustado que le recordaran como poeta lírico (Martínez 1982: 1002), la etiqueta de "escritor de cuentos" le acompañó durante su vida y le mereció ser considerado "maestro indiscutible del cuento del s. xx en nuestra lengua" (Merino 2012: 63). El cuento se adecua a su predilección por la concisión y la depuración del lenguaje, como él mismo afirma: "Está llenando mi vida literaria, que es como decir sencillamente que está llenando mi vida" (1995: 168). Lo muestra la publicación de numerosos volúmenes a partir de la década de los noventa, como Relatos de andar el mundo (1991a), Picassos en el desván (1991b), Las ciudades de Poniente (1994), Relatos sin fronteras (1998), Me gusta contar (1999a), Cuentos del Medio Siglo (1999b), Cuentos de la Cábila (2000) y Las ciudades de Poniente (2009), por el que recibió el V Premio Torrente Ballester. Poesía y cuento se encuentran entremezclados en su producción literaria y muestran estrechos nexos en su poética:

\begin{abstract}
Al tiempo que componía y publicaba mis poemas, cultivé la narrativa breve. El cuento literario tiene mucha afinidad con el poema y, además, en mi poesía -soy devoto del Romancero- no es difícil encontrar ingredientes narrativos. Por otra parte, la disciplina del verso me proporcionó recursos impagables para el relato: economía verbal, renuncia a los meandros y digresiones, poder de sugerencia de las palabras. (Pereira 2006: 358)
\end{abstract}

\footnotetext{
${ }^{1}$ Esta obra es reeditada en Cuentos del Medio Siglo (1999b).
} 
Estas confesiones del escritor permiten identificar la herencia que el género dejó en su alma: "La aportación que me hizo la poesía está en dos puntos; uno, el potencial de sugerencia de las palabras; otro, el sentido de economía procesal" (Pereira 1995: 168). Más allá de los préstamos de temas y motivos que presiden ambos géneros (el erotismo, el viaje y el encuentro, el autobiografismo) hallamos tonos semejantes: la ironía, el humor y el despliegue del ingenio. Junto a la fuente poética, la brevedad adquirida en el ejercicio periodístico ${ }^{2}$ tiñe también sus piezas narrativas y nutrió algunos microrrelatos.

De manera retrospectiva atribuyó también su dedicación al cuento a las circunstancias vitales que le llevaron a viajar dentro y fuera de España y que forjaron un talante disipado, que define en los siguientes términos:

\begin{abstract}
Para componer una novela o un largo ensayo hay que echar culo en la silla, pasar horas sobre los folios tratando de remedar o interpretar la vida mientras la vida está fluyendo naturalmente en la calle. O sea, que en los orígenes acaso me ha dado por escribir cuentos a causa de que soy un hombre "disipado" -no quiero decir calavera o libertino-. Ejerciendo seriamente la literatura, pero simultaneándola con otros oficios, traslados, traqueteos por muchos ámbitos. (Pereira 1995: 169)
\end{abstract}

\title{
2. Poética de La brevedad y microrrelato
}

Distante del realismo social que predominaba en los narradores de la generación del medio siglo (Ignacio Aldecoa, Medardo Fraile, Carmen Martín Gaite, Ana María Matute, Jorge Ferrer-Vidal) ${ }^{3}$ y de los componentes del grupo leonés (Luis Mateo Díez, José María Merino y Juan Pedro Aparicio), la vocación cuentística de Pereira transcurre al margen de los cánones estéticos imperantes y de la pertenencia a una generación. Aunque se sitúa en línea de continuidad de la tradición literaria del cuento desde El conde Lucanor, de don Juan Manuel hasta la mejor cuentística de los siglos xIx y xx ("Bola de sebo", de Guy de Maupassant; "Muerte en el aula. Un hecho real", de Walt Whitman; "William Wilson", de Edgar Poe; o los cuentos de Nathaniel Hawthorne, Álvaro Cunqueiro y Jorge Luis Borges, entre otros) prosigue un camino personalísimo e independiente.

Siguiendo la estela que trazaron Horacio Quiroga y Julio Cortázar en "Decálogo del perfecto cuentista" (1970) y "Del cuento breve y sus alrededores" (1969) respectivamente, el escritor leonés traza su propio decálogo en el prólogo a la selección personal de relatos Me gusta contar (1999a: 9-11). Expone aquí su concepción del cuento como fruto sabroso de tener una buena historia y saber contarla con laconismo; defiende la autarquía, brevedad e intensidad del

\footnotetext{
2 Sobresalen sus colaboraciones en diversos medios: El Sembrador, que editaba la congregación de los Operarios diocesanos; el semanario La parroquial berciana, que se editaba en la imprenta que su tío Tomás Nieto regentaba en Villafranca; en El Diario de León (entre 1964 y 1965), La voz de la Verdad, Las riberas del Eo, La Vanguardia Española (desde 1969 a 1974); en el diario leonés Proa (escribió la columna "Hojas de Papalaguinda") y en La Hora Leonesa (Rubio 2017), y también en $A B C$, Ya e Informaciones. Algunos de sus artículos han sido recopilados en Reseñas y confidencias (1985) y Crónicas de Villafranca (1997), publicados por la Diputación de León.

${ }^{3}$ Son referencias imprescindibles los estudios de Encinar y Percival (1993), Díez Navarro y González (2002) y Romera Castillo y Gutiérrez (2001).
} 
género; preserva la esfericidad y recomienda no diluir la historia con descripciones de relleno; y muestra que la maestría en el arte de contar tiene su génesis en la escucha de narraciones orales, en la lectura de cuentos y en la tendencia a vivir la vida más que a imaginarla (1999a: 9). Fiel a la creencia cortazariana de que la historia narrada ha de ser capaz con su potencia significativa de "actuar en el espectador o en el lector como una especie de apertura, de fermento que proyecta la inteligencia y la sensibilidad hacia algo que va mucho más allá de la anécdota visual o literaria contenidas en la foto o en el cuento" (1994: 371-372), Pereira subraya el poder memorable y el efecto único del género, como define en el mandamiento 6: "Que siempre haya expectativa. ¡Algo va a ocurrir!" (1999: 10).

A pesar de la tendencia in crescendo a la economía narrativa y al adelgazamiento de las historias que encontramos en el conjunto de su producción literaria, no posee el escritor leonés, a diferencia de Merino, Aparicio o Mateo Díez, un volumen de microrrelatos. No parece que tuviera la intención expresa de escribirlos ni conciencia genérica como narración diferenciada del cuento o de la poesía (Martínez 2010: 149). Hay algunos datos significativos, como el hecho de que cuatro microrrelatos de Picassos en el desván ("Lenta es la luz del amanecer en los aeropuertos prohibidos", "La violinista", "La esquela" y "El escalatorres") fueron incluidos por el autor como poemas en prosa en Meteoros. Poesía, 1962-2006 (2006); en el epílogo afirma Pereira: "El lector de mi poesía, si también lo es o ha sido de mis cuentos, encontrará en Viva voz cuatro [sic] textos que habiendo visto la luz como microrrelatos, valen, a mi juicio, como poemas. Me ha parecido un experimento jugoso..." (2006: 360). No nos detenemos en el proceso de depuración que llevó a cabo Pereira en la reescritura de estos microrrelatos al incluirlos en Meteoros, pues ya ha sido estudiado en profundidad por José Enrique Martínez (2010: 145-158).

Esta afirmación proporciona una de las claves que permite comprender el hibridismo y la naturaleza lúdica de su escritura; sin olvidar que el ser humano es un ser lúdico, Pereira hace del juego un instrumento de exploración literaria que le permite el acceso a la condición humana. Bien se le podrían atribuir las gozosas palabras que Vargas Llosa le dirigió a su maestro Cortázar: "Para él escribir era jugar, divertirse, organizar la vida -las palabras, las ideas- con la arbitrariedad, la libertad, la fantasía y la irresponsabilidad con que lo hacen lo niños o los locos" (2004: 15).

Como muchos de los cultivadores del microrrelato a comienzos del siglo xx (Andres-Suárez 2012: 26), Pereira llegó al género mediante un proceso de comprensión textual y de consunción de los componentes no narrativos y descriptivos del poema en prosa con el consiguiente incremento de la tensión narrativa a través de la elipsis, de lo que se sugiere y se silencia (Martínez 2010: 126).

También encontramos microrrelatos intercalados entre sus libros de cuentos, lo que intensifica el efecto desautomatizador en el lector. El primer volumen en el que aparecen es Picassos en el desván donde se atisba "como si el autor quisiera establecer un determinado ritmo de lectura" (González Boixo 
2004: 46); nos referimos a los titulados "Picassos en el desván", "El escalatorres", "Lenta es la luz del amanecer en los aeropuertos prohibidos", "La violinista", "Los pasadizos", "La esquela" y "The End". Con anterioridad había publicado "Una novela brasileña" en Los brazos de la i griega (1982). Y posteriormente aparecieron "Sesenta y cuatro caballos" en Relatos sin fronteras (1998); "El reconocimiento", en Cuentos de la Cábila (2000) y cuatros microrrelatos en La divisa en la torre (2007): "Seis palabras, cuatro pesetas", "Sacramento santo", "Pastoral" y "Postal de Ibiza"; en total, encontramos con una producción de catorce microrrelatos.

No nos detenemos en la fecha de publicación de los microrrelatos sino en su génesis, pues este estudio nos permite tomar conciencia tanto de los procesos de depuración, condensación y adelgazamiento que preside su obra como de las interrelaciones que el microrrelato entabla con la poesía (Varga Llamazares 2018) y con las anotaciones diarísticas y anécdotas autobiográficas (Rosell 2009).

\section{HibRIDISMO GENÉRICO. ANOTACIONES DIARÍSTICAS Y MICRORRELATO}

Algunas historias que configuran la trama de sus microrrelatos aparecen en Oficio de mirar. Andanzas de un cuentista (1979-2000), un volumen que recoge textos inéditos del escritor, anotaciones donde "el yo o yoes del dietarista se constituyen en sus referencias más externas y públicas, sean estas de carácter social, político o intelectual" (Alberca 2000: 15), lo que propicia la fabulación de los hechos, "en un campo ambiguo entre la invención y lo vivido" (Navascués 2019: 237). Así, junto a la narración de las andanzas del comerciante, de sus afinidades políticas o literarias, Pereira entrevera poemas, anécdotas y narraciones breves dotadas de ficcionalidad, que rescata y reescribe posteriormente como microrrelatos. Es esta una práctica que no extraña en un escritor que escribe al margen del canon y que acostumbra, en calidad de biógrafo de su vida, a construir una ficción fabuladora de la misma. De este fenómeno da cuenta en una anotación escrita durante una estancia moscovita en junio de 1974:

\section{Y MÁS RUSIA}

Moscú. Apenas escribo en mi diario. Rodando por Rusia, toda la atención me es poca para sujetar en papeles sueltos las experiencias que acaso me sean útiles. Un baile de boda en que me marqué un tango (o fox lento) con una rusa desconocida; el borracho con quien pude entenderme en francés y era un borracho triste, aquí estos desgraciados no gritan ni canturrean; mi negociación comercial con un pequeño Vania: él me ofrece una insignia de hojalata con el martillo y la hoz; yo, un bolígrafo (que le decepciona). Yo, una caja de cerillas españolas con faena taurina. Le gusta más, pero el negocio no se cierra. Saco una medalla de la Virgen milagrosa -oh, María sin pecado concebida...- ¡Y trato hecho! Todo esto puede dar algún relato, incluso un poema, pero también puede quedarse en nada. Desconfío de las páginas que se escriben encima mismo de lo que se está viviendo. La poesía es una emoción recordada. (Pereira 2019: 73) 
Estas y otras declaraciones del autor, como la contenida en el prólogo a La divisa en la torre: "Todo lo que el cuentista vive o imagina tiene vocación de cuento" (2007: 11) nos sumergen en la ficcionalidad de lo narrado. De esta manera algunas fabulaciones circulan de un libro a otro, tras sufrir alguna ligera transformación o poda. Nos detenemos en tres microrrelatos, a los que el escritor llega tras reducir el cuerpo textual y despojar la trama de lo de todo lo superfluo: "El reconocimiento", "Postal de Ibiza" y "Sacramento Santo", que analizamos brevemente.

"El reconocimiento" es el único microrrelato incluido en el volumen de treinta nueve cuentos de tono autobiográfico, que toma su nombre del barrio pobre de Villafranca del Bierzo, del barrio del Otro Lado, donde el narrador nació y vivió su infancia y adolescencia: Cuentos de la Cábila (2000); el protagonista es un chico del barrio, que llegó a literato y alcanzó de mayor el nombramiento de Hijo Predilecto de la ciudad:

\section{EL RECONOCIMIENTO}

A un chico de la Cábila que llegó a literato lo hicieron Hijo Predilecto cuando era mayor y le blanqueaba la barba.

Una noche pasaba el puente con un convecino que no tenía diploma honorífico y pensó que si un ventarrón los tirara al río, el predilecto sería el primero que salvarían.

La injusticia se le hacía insoportable, pero lo alivió el recuerdo de que en todo el barrio, él era el único que no había aprendido a nadar. (Pereira 2000: 137)

A quien conoce la vida del escritor no le pasa desapercibido que en 1976 fue nombrado Hijo Predilecto de su ciudad natal cuando contaba cincuenta años de edad y "era mayor y le blanqueaba la barba". Si el lector conoce la reciente publicación del dietario Oficio de mirar, sabrá que en una anotación titulada "Predilecto", fechada en octubre de 1976, alude al "escrito ceremonioso de firmas y sellos" en el que consta el nombramiento del Ayuntamiento, que reescribirá como microrrelato:

León, octubre 1976. He recibido un escrito ceremonioso de firmas y sellos, donde el Ayuntamiento de mi pueblo me nombra y declara Hijo Predilecto. Ya lo sabía, pero verlo en papel oficial renueva mi sentimiento de gratitud. También un poco de perplejidad. Hijo notorio, hijo distinguido, quizá algo así podría admitirse (y dejemos a un lado si con mayore o menores méritos). Pero predilecto... En el RAE, quiere decir "el preferido". Imaginemos que el señor Pepe el zapatero y yo vamos por el puente del Burbia y viene un ventarrón y nos tira al río. ¿Habrá de entenderse que yo tengo preferencia para que me salven? Bueno, debe ser que hoy no tengo mucho que hacer y con el rabo me espanto las moscas. Hijo Predilecto es lo que se dice por tradición, en Villafranca del Bierzo y en cualquier municipio de España. Conque bien está. Y sobre esa figuración del río, pues sí, quizá debieran sacarme a mí el primero, porque debo de ser el único en el pueblo que he aprendido a nadar. (Pereira 2019: 106) 
En este irónico apunte diarístico junto al recurso hegemónico de la primera, el escritor introduce un relato dentro de otro relato, mientras alude con humor e ironía al dicho popular que critica a quien derrocha y pierde el tiempo en tareas inútiles: "Bueno, debe ser que hoy no tengo mucho que hacer y con el rabo me espanto las moscas". Asimismo, se detiene en la acepción que el término "predilecto" adquiere en el RAE como "el preferido" para contar el dilema moral en que se encuentra. Mediante el proceso de identificación entre narrador y autor el lector se encuentra ante el "relato retrospectivo en prosa que una persona real hace de su propia existencia, poniendo énfasis en su vida individual y, en particular, en la historia de una personalidad" (Lejeune 1996: 50).

Si establecemos una comparativa entre la anotación del año 1976 (Navascués 2019) ${ }^{4}$ y lo publicado unos veinticinco años más tarde, observamos que la economía verbal le lleva a suprimir algunos detalles narrativos y descriptivos, como los referentes a los personajes (Pepe, el zapatero) o a la geolocalización de la historia (el río Burbia;) asimismo, el cambio de la voz narradora, de la primera persona a la tercera omnisciente, enfatiza la distancia e incrementa la interacción del lector; este se ve obligado, partiendo de las menores proposiciones explícitas en el texto, a realizar mayor esfuerzo intelectual para deducir la comprensión del contenido referencial y percibir el giro final. La depuración narrativa, la condensación de la trama y la estructuración en párrafos para diferenciar los niveles discursivos (la presentación del protagonista; la inclusión del relato dentro del relato para introducir la historia acaecida una noche y la reflexión ético-moral), la ironía suave y la mirada afectiva despliegan luminosidad a la anécdota de sustrato autobiográfico y refuerzan el quiebro y el dilema moral, que Ignacio Sanz denominó "retranca filosófica" (2012: 44), que se plantea en el desenlace: "La injusticia se le hacía insoportable, pero lo alivió el recuerdo de que en todo el barrio, él era el único que no había aprendido a nada" (2012: 731).

Son varios los rasgos que presiden el volumen Cuentos de la Cábila, subrayados por la crítica, que se pueden aplicar al microrrelato: el poder de la anécdota (González Boixo 2004: 54), la introducción de la perspectiva del autor en el punto de vista del narrador (Sanz Villanueva 2001) y la autorreflexividad que suscita para desvelar la ficcionalidad. Teniendo en cuenta que la metaficción es una ficción que reflexiona sobre la ficción (Hutcheon 1984: 1), Pereira reivindica con este recurso el papel del artificio en la literatura, enfatiza las fronteras que se alzan entre la vida real y la ficción e incorpora al lector a los actos de construcción textual-literaria y de la significación e interpretación semántica.

En el microrrelato "Postal de Ibiza" rescribe Pereira los recuerdos de su estancia ibicenca durante los últimos días del invierno, en el mes de marzo de 1977, según registra en Oficio de mirar (2019: 115-116). Posteriormente, tras la poda, el microrrelato fue incluido en La divisa de la torre, una de sus obras más maduras:

\footnotetext{
4 También pueden encontrarse el germen de microrrelatos dentro de una novela (de Mora 2012; Gómez Trueba 2012).
} 


\section{POSTAL DE IBIZA}

Cuando Ibiza empezaba a ponerse de moda, estuve en Ibiza. En Ibiza, ciertamente, había un solo benigno en pleno marzo y el sexo era fácil. Por entonces yo era un hombre libre. En la plaza Vara del Rey, coloreada de tipos y tipas variados, una de aquellas chicas soltó una paloma que llevaba cariciosamente en sus manos y vino a desearme una feliz primavera. Yo estaba entado en un poyo de piedra, observando y calentándome al sol. Se sentó a mi lado y con naturalidad me convidó a la mitad de la manzana que estaba mordiendo, yo mordí, y ni pensar en microbios. De un librito forrado con papel de envolver de los almacenes La Fayette me leyó unos versos algo simples de Francis Jammes, justo un poema que recuerdo de mis tiempos de la Alianza Francesa:

Le papillons obéissent à tous les soufflés,

Comme des pétales de fleurs jetés vers vous,

Aux processions, par le petits enfant doux.

La chica me había parecido enfermiza, con una falda hasta los pies que se le pegaba a los muslos finos y muy largos, pero cualquier aprensión se te quitaba mirándola a la boca, no puede haber mala salud en una mujer que muerde la fruta con aquellos dientes. Y el color tan vivo de los labios. Yo había alquilado un coche pequeño y casi sin frenos, suficiente para una isla diminuta y juntos la recorrimos. Juntos también nos acostamos en una venta tolerante, en un pueblo blanquísimo. La flaca tenía un follar laborioso y callado. Lo que más me gustó de la "religión" de esta gente es que nos despedimos sin preguntarnos nuestros nombres. (Pereira 2007: 127-218)

Mientras abandona algunos recuerdos de su visita a proveedores o clientes (la abundancia de hippys, escasamente convencidos de su religión, y de perros en la isla) y selecciona una vivencia para focalizar la narración en el encuentro con la muchacha "astrosa y enfermiza" y rescribir algún pasaje novedoso, como la travesía en coche, recupera Pereira los versos de Francis Jammes, uno de los poetas franceses más soslayado y situado en los márgenes del sistema literario a finales del siglo XIX, subrayando así el lirismo que impregna su obra en prosa. Los versos en los que el poeta revive el canto a la naturaleza tiñen de gracia y espontaneidad el microrrelato, en el que concilia la sugestión poética y el arraigado sentido lo humano. "Postal de Ibiza" es reflejo de la predilección del narrador por la estética de contención y de la depuración estilística. Como poeta liberado de los imperativos literarios genéricos, extiende la metáfora a la contemplación de la muchacha y muestra su pensamiento con naturalidad y belleza.

El tercer microrrelato en el que la tendencia a la brevedad le conduce a exacerbar los espacios de indeterminación es "Sacramento Santo", que publica también en La divisa en la torre:

En un pueblo de la Mancha oímos una copla que debería resultar obscena, y no, y esto tenía caviloso a mi amigo el lingüista de semióticas y campos semánticos. Descubrió al fin que es una simple palabra la que desactiva cualquier procacidad en el texto: 
Sácala, marido, que la quiero ver.

¡Dios te la bendiga!, vuélvela a meter.

La palabra marido. (Pereira 2007: 153)

Se nutre "Sacramento Santo" de la vivencia acaecida en Madrid durante el mes de mayo de 1998, que anota en Oficio de mirar bajo el paratexto "De Lingüística":

Madrid, mayo 1988. Esta es la coplilla que he escuchado en La Mancha, en un ambiente de gente sin complicaciones:

Sácala, marido, que la quiero ver.

¡Dios te la bendiga!, vuélvela a meter.

La encuentro un encanto y se me ocurrió comentarlo con un lingüista. Se puso a analizar el discurso y dijo que era fácil de descodificar, pero me llevó a la Semiología, se metió por los campos semánticos y concluyó que al final influye la competencia cultural del receptor.

Ya por cuenta propio, deduzco que es la palabra "marido" la que desactiva cualquier procacidad en el breve texto, ingenuo y familiar. (Pereira 2019: 235)

Son distintas las transformaciones sufridas; oscilan desde el cambio íntegro del título hasta la depuración de la trama mediante la supresión del fragmento en el que refiere el análisis semiológico de la coplilla realizado por un lingüista experto, lo que enfatiza el hecho de que la estructura macroestructural subyacente a la superficie textual del microrrelato se muestre velado a quien carezca de la competencia cultural pertinente. La eliminación del párrafo descriptivo sobre la descodificación del término, la concisión extrema y la síntesis narrativa ensalzan la provocación, la parodia y el juego intertextual (copla popular o la huella cervantina) como armas de las que dispone Pereira para el tratamiento del erotismo.

En este microrrelato la expresión erótica se sirve del juego lingüístico y de la paradoja planteada entre las expectativas de lectura suscitadas por el título ("Sacramento Santo") y los mundos referenciales que custodia la narración. La interpretación del significado semántico que se deriva del contenido dialógico que mantienen los protagonistas de la copla precisa la descodificación de los contenidos implícitos. De manera inesperada la voz narradora quiebra las expectativas creadas y suscita repentinamente otros niveles de significación; subvierte los campos semánticos y desestabiliza el orden previsto, dando entrada al humor. Y con el humor aparecen la sorpresa y el cambio de perspectiva que va más allá de la pura comicidad.

\section{LA FORJA DE LA BREVEDAD EN EL PERIODISMO}

En ámbito del periodismo el primero de los microrrelatos publicados es "Una novela brasileña"; aparece a comienzos de la década de los ochenta en el cuarto volumen de cuentos del autor, Los brazos de la i griega (1982: 75) y posteriormente fue incluido también en Me gusta contar (1999a: 67): 
O Capitão do Exército Agenor Araújo de Medeiros, 39 anos, foi assassinado no final da noite ao tentar reagir a um assalto na Rua Bertolini, próxima à Praia Branca, em Guanabara. O militar estaba no seu carri em compañía de Palmira Fernandes Oliveira quando dois criminosos surgiram de arma em punho. Agenor morreu antes de ser socorrido no Hospital Bom Jesus da Estrela. Era casado com Fernanda Valéria Martins Costa com quem tinha uma filha de sete anos. A ocorrência ficou registrada. (Pereira 1982: 75)

Esta miniatura narrativa revela que el mundo ficcional narrativo se nutre de las noticias leídas en la prensa, en concreto, de la trágica noticia del asesinato al anochecer de Agenor Araújo de Medeiros cuando se encontraba en compañía de una señora, que no era su mujer. La noticia constituye el eje narrativo. Como si de un atestado judicial se tratara, de manera concisa se registran minuciosamente los hechos acaecidos durante una noche madrileña, mientras se tiñe de ambigüedad a medida que se avanza en la lectura. Los elementos elididos potencian la tensión dramática e incrementan el misterio; de manera velada se alzan una sucesión de interrogantes y figuraciones, que requieren la implicación de un lector activo que pueda dar respuesta a las cuestiones que el escritor villafranquino también se planteaba en la lectura que hizo de esta historia en un filandón en 2006: qué pensaría la esposa, qué explicación se le daría a la hija acerca de la presencia de esa mujer en la noche de autos, cómo se llegaría a esa situación, etc.; en suma, con la estructura elusiva la historia, desvinculada del contexto en que apareció, se tiñe de referencias metaliterarias, potencia la ficcionalidad y enfatiza el juego entre el humor y el erotismo, que preside otros cuentos de este volumen (González Boixo 2004: 38).

Es esta una práctica que vertebra otros microrrelatos, algunos recogidos en la colección Picassos en el desván, como el microrrelato homónimo (1991: 41) y "La esquela" (1991:155), ${ }^{5}$ a partir de la aparición en $A B C$ de la esquela de la condesa de la Plana y de Santarcángelo:

En la mesa de mármol del casino estaba el $A B C$ memorioso y decía, doña Helena de Fiore de Luna y Pérez de la Plana, Condesa de la Plana y de Santarcángelo, falleció en accidente en La Spézia (Italia) el día 31 de mayo de 1986. Hay una cruz, hay una esquela honrosa, sus padres los condes, sus hermanos los condes.

La Condesa Helena contaba diecinueve años de edad y en la tarde del casino de un pueblo como el nuestro, era imposible no ver una verja de hierro entornada, una fuente en un parque, el cuello de una estatua. (Pereira 1991b: 155-157)

Un narrador en tercera persona desvincula el relato del formato de la esquela (aunque no deja de aludir a ella) y focaliza la atención en la vida de la joven condesa y en el espacio opresor en el que transcurrió su vida. Nos encontramos ante un bosquejo descriptivo de la trama que, como algunos cuentos de Chéjov, se resiste al análisis, aunque invita al despliegue de la imaginación en el acto de

${ }^{5}$ Fue también recogido sin variantes textuales en Me gusta contar (1999: 143). 
lectura; la frescura narrativa se impone al tratamiento costumbrista y a diferencia de la narrativa breve del escritor ruso no sustituye la acción argumental por la interna.

En el microrrelato "Picassos en el desván"6 -incluido sin variantes en Me gusta contar (1999a: 111)- juega Pereira a trazar de manera sucinta el contenido de la noticia aparecida en un periódico en torno a la aparición de tres picassos en el trastero del fallecido párroco de Priegue, mientras invita a reflexionar sobre el proceso de creación literaria:

\begin{abstract}
Una vez estaba el novelador en una ciudad lejana y prometedora de fabulaciones cuando tuvo en las manos un periódico de su propio país y en él venía la noticia breve de tres picassos hallados en el trastero del difunto párroco de Priegue en el municipio pontevedrés de Nigrán, o sea un gouache de la época rosa del pintor más un retrato de madera de su prima María Ruiz más un temple sobre tela con una figura inacabada, y la adquisición tuvo lugar en 1920 (Maura sí) cuando el párroco fue requerido por su ordinario (los exhortos, las audiencias, la sagrada amatista) para que vendiera unas casas de su propiedad sitas en un barrio de Vigo poco acorde con la moral cristiana y el requerido vendió sus casas (los tasadores, el notario) y con los cuartos frescos marchó a París (Monforte, Venta de Baños, Hendaya), el cura de Priegue en el París de los hoteles con agua corriente y bidet mercando las obras por 28.000 pesetas (el fauvismo, el cubismo, el Moulin Rouge), y el novelador ni caso, busca que buscarás argumento para una novela río. (Pereira 1999: 41)
\end{abstract}

No es el único microrrelato en el que uno de los personajes es un escritor, editor o personalidad del mundo literario a través del cual Pereira plasma su teoría sobre la creación literaria y su preferencia por ofrecer ángulos insólitos de la realidad. El juego preside la pieza y se convierte en un refugio para la imaginación del escritor y del lector, que es invitado a descubrir las trampas que se esconden tras el novelador y los protagonistas (el párroco difunto y su ordinario), tras las fabulaciones de una lejana ciudad y otros espacios (el trastero, el barrio de la ciudad de Vigo, los hoteles parisinos) y el objeto en torno al cual gira la trama: los "tres picassos hallados en el trastero del difunto párroco de Priegue". El resquebrajamiento de la realidad tiñe la pieza de la ambigüedad propia de la literatura fantástica, hasta el punto que el lector no acierta a saber si lo que se le cuenta es real o una alucinación del novelador.

\title{
5. Microrrelatos metaficcionales
}

Como vamos observando, los juegos y las reflexiones metaficcionales sobre el proceso creador tienen presencia destacada en la narrativa breve de Pereira, tanto en sus cuentos y microrrelatos, como "El escalatorres", "Lenta es la luz del amanecer en los aeropuertos prohibidos", "The End" o "Sesenta y cuatro caballos", incluidos en Picassos en el desván, un volumen donde este tema adquiere

${ }^{6}$ Este microrrelato fue incluido en Dos veces cuento. Antología de microrrelatos, de José Luis González (1998). 
cierto protagonismo. Nos detenemos brevemente en el titulado "El escalatorres", incluido en Me gusta contar (1999a: 150):

Un oficio que da muchas emociones es el de escalatorres, pero es un cuerpo en el que cuesta trabajo entrar porque ha quedado en manos de pocas familias. Hay un escalatorres jubilado que relata su conocimiento eminente del país: los prados extendidos y los campos de mieses, las humildes chimeneas y los caserones humillados de los señores.

Pero no es lo mismo una torre de ayuntamiento que la experiencia desde cúpula de catedral. Y aun en esta, la visión del escalatorres puede ser exaltada o serena, según sea gótico o románico al monumento que se encarama.

Con todo, lo que a él le importaba más era su facultad de descifrar la condición humana desde la altura.

Cuenta de ciudades cultas donde la escalada es como un concierto de música al que asiste en silencio, ciudades avaras enumera donde el público desaparece a la hora de la colecta, pero también ciudades generosas y de brazos abiertos. En Osorno, provincia de Palencia, se cruzan apuestas sobre el espectáculo sin cuidar por eso de las barajas. En la ciudad empedernida (pero de esta no dice el nombre) alienta el deseo de ver cómo el artista se desprende de un saliente y se mata. (Pereira 1991b: 51-54)

Persigue Pereira convertir al lector en copartícipe de una historia de corte fantástico, en la que ha de desgranar las conjeturas que se le plantean. Son varios los niveles de lectura convocados. El microrrelato se deja leer de manera superficial como el devenir de un oficio, el de escalatorres, un hombre araña capaz de ascender a elevadas alturas para convertirse en el mítico rey de las alturas; la figura del equilibrista fue una aspiración popular, que encarnó a finales del siglo XIX el joven José Puertollano, vinculado al Circo Feijoo, que consiguió la autorización del rey Alfonso XIII para escalar las torres de España. Más allá de la tipología urbanística trazada por el escritor, puede el lector remontarse a los orígenes de la profesión hasta llegar a Antonio Sousa, quien en 1934 escaló la torre de la catedral de Lugo para desempeñar labores de limpieza y un año antes se había caído al escalar la fachada del Ayuntamiento de La Coruña. Sin embargo, más allá del espectáculo, mediante la ironía, la contaminación del discurso del autor implícito con el del narrador y el del personaje y mediante el recurso gradual a la focalización interna, Pereira introduce al lector en un gremio, que no dista mucho del suyo propio, el del escritor que pretende escalar y consagrarse en la historia de la literatura, mientras en el alma de muchos contemporáneos "alienta el deseo de ver cómo el artista se deprende de un saliente y se mata".

En "Lenta es la luz del amanecer en los aeropuertos prohibidos" -incluido en Me gusta contar (1999a: 166)- llaman la atención la ironía, que despliega el escritor mediante el contraste entre la longitud del paratexto principal y la brevedad de la pieza, y el aliento poético que inspira la tarea del poeta y la misma miniatura narrativa:

Una vez estaba Pepín Ramos el poeta inspirado en la taberna que llaman el Senado, sentado a la mesa tosca, haciendo su papel de poeta inspirado. Todos 
lo respetamos mucho en sus esperas de la voz misteriosa, aunque nunca se le haya visto una página terminada. Vino un parroquiano de la taberna con la alegría lúcida de los primeros vasos, y fisgó el renglón que campeaba en la hoja: Lenta es la luz del amanecer en los aeropuertos prohibidos.

El verso hermoso, todavía único, con que iba a arrancar el poema.

El parroquiano suspiró:

-Es un buen empiece, Pepín. Pero ahora qué. (Pereira 1991b: 77-79)

Mientras el verso del poema inacabado de Pepín Ramos, poeta inspirado que no termina nunca una página, traza el profundo lirismo que tiñe la historia, la mirada socarrona del parroquiano habitual de la taberna sugiere la dificultad que entraña el ejercicio de la escritura. Junto a la voluntad de estilo y la sutil incorporación del registro oral, sobresale el humor velado e inteligente del desenlace que suscita la sonrisa del lector y tiene su contestación en uno de los principios que integra el decálogo del escritor: "Cuidar el comienzo, entrando rápido en el tema. El final sabe cuidarse solo" (1999: 10).

La elipsis y el juego entre lo dicho y lo silenciado como instrumentos al servicio de la economía lingüística y de la densidad semántica de la narración enfatizan el intimismo contenido ("Lenta es la luz del amanecer en los aeropuertos prohibidos") y apuntan a la formulación metaliteraria: "Es un buen empiece, Pepín. Pero ahora qué". El valor sugestivo del título, que lleva al lector a intuir el encuentro amoroso, es elidido en la trama y recuperado en un final abierto, que devuelve una significación potenciada: el pánico ante la hoja en blanco, la dificultad de una escritura que solo es sencilla en apariencia, y la prolongación de una historia de amor apenas apuntada, lo que obliga a que el lector descodifique los sentidos sobreentendidos en los espacios en blanco.

En el microrrelato "The End", incluido en Me gusta contar (1999a: 180), Pereira con el arpón de la palabra y de la imagen ansía la búsqueda de una realidad más honda:
Al saberse que iban a derribar el cine municipal los teléfonos empezaron a fun- cionar y fuimos bastantes los que viajamos a nuestra ciudad para decir adiós al caserón donde habíamos aprendido tantos gestos.
Había que adelantarse a la piqueta desalmada. Cada cual quería quedarse con un recuerdo, los viejos carteles de un transatlántico con las luces encendi- das o de apariciones de la Virgen o de los besos de tornilla de una espía rusa.
Al final, decidieron que habría una voladura controlada. Sería la última pe- lícula que nos diesen.
Pero el espectáculo fue que al estampido de la dinamita se espantaron los caballos de la Remonta y rompieron vallas y galoparon las calles, y todos caímos en la cuenta de que no hubiera podido existir el arte del cine si no se hubieran levantado los caballos. (Pereira 1991b: 167-169)

Destaca la esfericidad de este microrrelato cuya interpretación cobra sentido desde el título cinematográfico. Desde las primeras frases la sorpresa invade y arrastra al lector de manera avasalladora. Los espacios vacíos, las cosas no dichas o levemente sugeridas forman parte de la estrategia narrativa y de los guiños 
textuales al lector para que como principio activo de la interpretación forme parte del marco generativo del propio texto. La imagen visual de la voladura controlada del caserón del cine municipal se apodera de la voz narradora que recorta de manera progresiva un fragmento de la realidad; de manera semejante a como la fotografía actúa "como una explosión que abre de par en par una realidad mucho más amplia" (Cortázar 1994: 371-372), el golpe de efecto que provoca la dinamita sobre los caballos de la Remonta se apodera tanto del escritor, que alimenta su imaginario narrativo con la propia vida, como del lector. La reflexión metaficcional está servida.

"Sesenta y cuatro caballos" -también incluido en Me gusta contar (1999a: 202) - cierra Relatos sin fronteras, volumen de diecisiete breves narraciones (algunas inéditas), que van acompañadas con unas palabras preliminares "Confesiones del autor", donde expone la tesis de raigambre ramoniana de que la clave del cuento reside en la exageración de una realidad:

Los Pereira (o Pereyra) que salen en las enciclopedias heráldicas se nos hacen algo molestos a quienes somos sus parientes de la rama pobre, y es por lo tacaños y esa manera que tienen de saludar, como si diesen los buenos días desde encima de la montura.

Ellos descienden derechamente de don Gonzalo Pereira, pero poco se parecen al antepasado dadivoso.

Lo escribió Pedro de Bracelos: Que teniendo el don Gonzalo treinta y dos caballos, en un solo día regaló todos a distintas personas. La cosa huele a invención y adorno.

Pero sigue la Crónica con que en ese mismo día los volvió a comprar don Gonzalo, aquellos treinta y dos caballos, para así poder regalarlos a otras tantas personas de su estima, y entonces el caso se hace creíble, porque a los escuchadores de historias nos resulta más fácil aceptar lo enorme que lo mediano. (Pereira 1998: 119)

La frase de cierre, "a los escuchadores de historias nos resulta más fácil aceptar lo enorme que lo mediano" se tiñe de una fuerte resonancia intertextual; evoca las palabras con que Gómez de la Serna en Automoribunda hace referencia al consuelo que encuentra en "la exageración de las cosas, en la multiplicación de la realidad, en los subterránenos de una casa de pianos", que el escritor recoge en el prólogo citado (Pereira 1998: 7). Estamos ante un microrrelato metaliterario que sitúa a Pereira en la escuela de la narrativa de Cunqueiro con el reclamo de la reflexión sobre la literatura en el universo de sus ficciones. Sobresale la inventiva del escritor en la narración de sucesos peregrinos, como la recreación de los orígenes heráldicos de la familia o del personaje don Gonzalo Pereira, quien supera en riqueza al narrador, de quien se dice que pertenece a la rama pobre y menos legendaria de la familia. Subraya así la incorporación al texto de la figura del escritor (Waugh 1984: 130), un recurso metaficcional que Genette definió como metalepsis (1972: 244) para desvelar desde la ironía otro decálogo de su poética: "El novelista puede ser altanero. El cuentista debe ser cordial y amistoso" (Pereira 1999: 11). 


\section{LA INSINUACIÓN Y EL HUMOR EN EL EROTISMO}

Antonio Pereira, a quien Antonio Gamoneda considera, además de narrador afiladísimo, inventor del erotismo diocesano (1997: 109), desliza de manera sutil en el alma de los personajes que pueblan su narrativa breve el aliento erótico. Lo hace de modos diversos, ya con sutileza mediante una leve insinuación, o con cierta audacia, mediante el recurso al humor y a la ocurrencia. Si el erotismo es el eje temático de algunos cuentos de Una ventana a la carretera ${ }^{7}$ y de Los brazos de la i griega, también está presente en sus microrrelatos, aunque es diverso el tratamiento que recibe. Nos detenemos en los titulados "La violinista", "Los pasadizos", "Seis palabras, cuatro pesetas" y "Sacramento Santo".

En ocasiones el genio narrativo de Pereira se sustenta en el extraordinario poder de evocación y de sugestión que le permite filtrar la materia literaria y provocar el máximo efecto con los mínimos elementos posibles. Lo observamos en "La violinista", que era -como cuenta el escritor en una anotación de sus diarios, uno de los preferidos de Ricardo Gullón (2019: 263)- y que fue incluido sin variantes en Me gusta contar (1999a: 175). Dice así:
A veces viene a la provincia la Sinfónica de Bratislava o una lejanía así.
Es una novedad, pero no toda la novedad está en la música.
Esa chica del violín que en la orquesta está lánguida de melena y a lo me- jor se llama María o Claudia, educada para la vibración casi celeste, trémolos, pizzicatos, a esa mujer vestida de raso ni se le ocurre que en la sala hay ojos codiciosos de hombres que la apartan a ella del conjunto e imaginan juegos de amor para sus manos, dedos. (Pereira 1991b: 99-101)

Un aparente acontecimiento trivial, la llegada de una orquesta, desata una oleada de novedades en la vida rutinaria de una ciudad provinciana, y despierta a sus habitantes. Si la alusión a la procedencia de un mundo lejano ("Bratislava o una lejanía así") evoca un universo nunca soñado, la focalización de la atención en los aspectos corporales sexuales de una de las mujeres que integra la orquesta sostiene el imaginario narrativo. Una anónima mujer "vestida de raso" ("a lo mejor se llama María o Claudia") permanece en silencio y en estado de sumisión, como veladamente da a entender la voz narradora al mostrar el letargo en que se encuentra: "ni se le ocurre que en la sala hay ojos codiciosos de hombres que la apartan a ella del conjunto e imaginan juegos de amor para sus manos, dedos". La ensoñación que provoca la llegada de la muchacha desencadena las pasiones de quienes centran la mirada en la lánguida chica del violín, capaz de alimentar su libido. Es la alteridad, proyectada en los "ojos codiciosos" de los hombres que habitan la sala, la que imagina el cuerpo y construye la simbolización del deseo erótico (Blanchot 1983; Bataille 1997) como sexualidad transfigurada. Y desde el vértigo metafórico designa el escritor una realidad que se halla más allá de los términos que la originan: el anhelo del goce erótico.

\footnotetext{
7 Es el eje de los cuentos "Una ventana a la carretera", "Santa Bárbara cuando truena" o "Hermosa primavera Sr. Director".
} 
No presenta el narrador una historia cerrada, sino que esta se abre como un chispazo. La poetización y musicalidad de la prosa, las elipsis y connotaciones y las sugerencias y alusiones veladas alcanzan una de sus máximas expresiones líricas y potencian las posibilidades semánticas y estéticas de la sustancia narrativa, que se teje en torno a una anécdota mínima. Como un orfebre del lenguaje Pereira pule cada palabra y cada gesto y entreteje con sutileza e ironía un erotismo delicado y suave, cuya interpretación se deja a la intuición y a la sensibilidad del lector. Plasma esta miniatura narrativa los rasgos configuradores de estilo pereiriano: la depuración del erotismo y la condensación de la anécdota; el poder de sugerencia y la multiplicación de sentido; la máxima concisión lírica y la musicalidad del ritmo narrativo; la precisión lingüística, las elipsis y los silencios. Reúne, en suma, los tres rasgos que ha de reunir un microrrelato, según Mateo Díez: ha de ser sugestivo, sugerente y significativo: "Una sugestión que es una atracción, un cierto poder que moviliza la curiosidad y os hace partícipes acaso embelesados del relato, desde el sustrato del mismo. Una sugerencia que insinúa, despierta, sustrae nuestro ánimo del modo insospechado, placentero, enriquecedor" (2008: 533).

Antonio Pereira, fiel al precepto cortazariano de mantener la apertura de la brevedad hacia lo grande, descubre la riqueza de la materia narrativa y la dota de gran significación mediante la administración de lo que cuenta y calla, de la imprescindible condensación al servicio de la intensidad. Lo observamos en el microrrelato "Los pasadizos", que fue incluido sin variantes en la colección Me gusta contar (1999a: 156):

Hay una ciudad apiñada que está hecha de contigüidades, medianerías y gravámenes que alimentan a los abogados y procuradores y registradores de la propiedad y, sobre todo, está el asunto de los pasadizos, que garantizan pleitos largos como para llenar una vida.

Por el pasadizo del barón se entra en una de las casas principales de la Costanera, pero se pasa también a dependencias que son de Correos, a un gallinero pro indiviso de cinco hermanos, que el mayor está en Venezuela, y a una capilla de culto privado. Hay un callejón de la fábrica de harinas por donde se entra obligadamente a una escuela de permisos de conducir establecida debajo de un cuarto con desván donde radica la asociación de canaricultores. Los vecinos del barrio de arriba tienen derecho a pasar con sus botijos a la fuente del Pozo, que por laboriosos avatares se ha quedado en el medio del cuarto de estar de una viuda anciana. Y solo son ejemplos.

En las casas nuevas, las que se construyen ahora, los colindantes se ponen de acuerdo para dejar callizos y servidumbres de paso que les aseguren una vejez animada. (Pereira 1991b: 125-128)

Evoca el título la fascinación cortazariana por todo lo que es pasaje (González Bermejo 1986: 52-53). Confiere Pereira un valor simbólico a los espacios: el pasadizo del barón, el cuarto con desván, los callejones y las servidumbres de paso tienen el poder de entablar insospechadas relaciones entre los habitantes de la "ciudad apiñada"; y maneja con maestría otros recursos que están al servicio de la narratividad y de la progresión dramática: la reducción de la caracterización 
de los personajes (son anónimos "abogados, y procuradores y registradores de la propiedad", "vecinos del barrio", una "viuda anciana"), la relevancia semántica de los componentes estructurales que lo conforma y, el polisémico título ("Los pasadizos). El desenlace abierto, con la alusión al pasadizo como estructura arquitectónica capaz de asegurar "una vejez animada", alienta el fino erotismo que sustenta la narración, pues permite recibir multiplicidad de lecturas, tantas como lectores las lean.

Aunque Antonio Pereira juega con el tema erótico casi siempre desde la insinuación, prolongando la historia sin llegar a la descripción frontal, en otras ocasiones la alusión es directa, como percibimos en el microrrelato "Seis palabras, cuatro pesetas":

La criada de la señora que me tenía de pupilo se llamaba Benigna, estaba buena para mis primarias necesidades de entonces y me consentía tocamientos por encima de la ropa. Pero sobre este tema de la pensión no quiero extenderme, porque irremediablemente se hace literatura de costumbres, que no sé por qué está tan mal vista.

Benigna se arreglaba mal con la escritura, yo le hacía los sobres para su novio, pero no las cartas. El novio venía a verla de tarde en tarde, cuando juntaba para el viaje a fuerza de ahorrar y de horas extraordinarias.

Un día coincidí con Benigna en la ventanilla de Telégrafos y el funcionario estaba agobiado y exigía que se le diera completo el impreso. La chica miraba angustiada a su alrededor y al verme se puso colorada y pareció como si titubeara, pero me alargó el papel para que se lo cubriera. Los telegramas eran baratos y aun así se limitaban a casos de mucha desgracia. Con letra clara escribí el dictado desgarrador:

No vengas estoy con el mes. (Pereira 2007: 55-56)

El componente erótico, mostrado a través de la reivindicación del mundo íntimo de los personajes (Benigna y el pupilo de la señora) y de la relación entre la sexualidad y la palabra, contrasta con la dimensión social que adquiere a través de la plasmación de la transgresión y los conflictos que se desencadenan: "Pero sobre este tema de la pensión no quiero extenderme, porque irremediablemente se hace literatura de costumbres, que no sé por qué está tan mal vista". Desde esta perspectiva permite que el lector indague sobre las normas establecidas en un entorno que comprende las referencias a las condiciones económicas ("la criada de la señora") y culturales: "Benigna se arreglaba mal con la escritura, yo le hacía los sobres para su novio, pero no las cartas". Cobra un papel destacado por su función decodificadora el enunciado final, con que cierra la pieza narrativa: "No vengas estoy con el mes", pues permite "actualizar una serie de marcas cuyas connotaciones no se presentaban del todo sustentables hasta esa instancia" (Fernández Ferrer 1990: 132).

Si bien está presente en el tratamiento pereiriano del erotismo la fascinación por la belleza o la transgresión de la pasión amorosa, dista de mostrar los aspectos sórdidos, como la crueldad y la violencia en las relaciones. Junto a la preferencia por un contenido intimista, muestra también la resistencia frente a la moral convencional, como observamos en el siguiente microrrelato: 


\section{PASTORAL}

Era un hombre como cualquier otro de los que ves por la calle, solo que este iba encogido en ropas reverendas que parecían pesarle.

A mitad del viaje preceptivo, ya en el territorio de las minas, le apuraba la próstata y se apeó del coche en el lugar que le pareció más a salvo, pero lo vieron y desde unos desmontes de la hulla bajaron voces de burla:

"iQue se la corten!" "Que se la corten!"

"Vaya por Dios", y por primera vez se miró con ternura aquella cosilla que en una larga vida solo le había servido para evacuar. El secretario esperaba junto a la portezuela entreabierta, pero el hombre de las ropas reverendas se detuvo y trazó la señal de la fe hacia los hombres del carbón, y es probable que ellos vieran allá abajo no más que un resplandor fugaz, sin saber que lo daba la amatista, sin saber qué es una amatista. (Pereira 2007: 4)

Consciente de que un cuento o un microrrelato "es la ficción de una voz", explota Pereira "la voz imaginada del narrador" (1999: 11), que se presenta cargada de un profundo humanismo tanto en los temas como en la forma de expresar los sentimientos. Los protagonistas dialogan con la soltura y la espontaneidad que fluye del habla cotidiana y la lengua está tan trabajada, es tan transparente y clara que el lector puede tener la impresión de que es hablada. Como es sabido, el escritor sometió su narrativa a una continua labor de poda, que está al servicio del rigor de la composición y de la palabra exacta. La precisión de la forma artística es condición de la brevedad, como recoge en el decálogo mencionado: "Si dudas entre dos palabras, elige la más clara. Si hay empate, quédate con la menos prestigiosa" (1999a: 10).

Frente a quienes han defendido la dependencia del microrrelato respecto al cuento (Mora 1983; Pratt 1981) y se han referido a él como forma próxima a la fábula y al poema lírico (Howe y Howe 1983: IX-XIV), consideramos que, aunque el cultivo del género no transcurrió al margen de las vías de renovación del cuento entre las décadas de 1940 y 1950, ha alcanzado autonomía respecto a dichas modalidades textuales, lo que le permite vivir como género independiente (Calvo 2012: 15-36).

El estudio realizado nos lleva a disentir en esta ocasión de la tesis de Irene Andres-Suárez cuando considera que no estamos ante microrrelatos sino ante "anécdotas o noticias con un notable componente lírico" (2012: 56). Más allá de permitir que la historia se quede en "anécdota, chascarrillo, ocurrencia" -así lo expone en el segundo decálogo (1999a: 10), Antonio Pereira tiene muchas historias que contar y las narra de modo diverso. Sus historias, como sostiene David Lagmanovich, "no son abreviatura de nada, sino construcciones absolutamente autónomas que imponen su presencia en virtud de una estructura que aspira a la perfección" (2006: 41). Cada una cobra vida propia, como "la pompa de jabón de la pipa de yeso", de que habla Cortázar en "Del cuento breve y sus alrededores", o como los picassos de la época rosa que se custodian en el desván. 


\section{OBRAS CITADAS}

Alberca, Manuel (2000). La escritura invisible. Testimonios sobre el diario íntimo. Oiartzun: Sendoa.

Andres-Suárez, Irene (ed.) (2012). Antología del microrrelato español (1906-2011). El cuarto género narrativo. Madrid: Cátedra.

Bataille, George (1997). El erotismo. Barcelona: Tusquets.

Blanchot, Maurice (1983). El libro que vendrá. Caracas: Monte Ávila.

Calvo Revilla, Ana (2012). "Delimitación genérica del microrrelato: microtextualidad y micronarratividad", in Las fronteras del microrrelato. Teoría y crítica del microrrelato español e hispanoamericano, ed. Ana Calvo Revilla y Javier de Navascués. Madrid/ Frankfurt: Iberoamericana/Vervuert, 5-36.

Cortázar, Julio (1994). "Algunos aspectos del cuento", in Obra crítica. Madrid: Santillana.

Cortázar, Julio (1969). "Del cuento breve y sus alrededores", in Último round. México: Siglo $\mathrm{XXI}$.

Díez, Luis Mateo (2008). "Ideas, medidas, historias", in La era de la brevedad. El microrrelato hispánico, ed. Irene Andres-Suárez y Antonio Rivas. Palencia: Menoscuarto, 531-535.

Díez Navarro, Epicteto, y José Ramón González (2002). El cuento español en el siglo xx. Madrid: Alianza.

Encinar, Ángeles, y Anthony Percival (eds.) (1993). Cuento español contemporáneo. Madrid: Cátedra.

Fernández Ferrer, Antonio (ed.) (1990). La mano de la hormiga. Los cuentos más breves del mundo y de las literaturas hispánicas. Madrid: Fugaz.

Gamoneda, Antonio (1997). El cuerpo de los símbolos. Madrid: Huerga \& Fierro.

Genette, Gerard (1972). Figures III. París: Seuil.

Gómez Trueba, Teresa (2012). "Entre el libro de microrrelatos y la novela fragmentaria: un nuevo espacio de indeterminación genérica", in Las fronteras del microrrelato. Teoría y crítica del microrrelato español e hispanoamericano, ed. Ana Calvo Revilla y Javier de Navascués. Madrid/Frankfurt: Iberoamericana/Vervuert, 37-52.

González Bermejo, Ernesto (1986). Revelaciones de un cronopio: conversaciones con Cortázar. Buenos Aires: Contrapunto.

González Boixo, José Carlos (2004). "Introducción", in Antonio Pereira. Recuento de invenciones. Madrid: Cátedra, 13-77.

Gullón, Ricardo (1991). "Picassos en el desván. Antonio Pereira", ABC, 23 de febrero.

Howe, Irving, e lliana Wiener Howe (eds.) (1983): Short Shorts. An Anthology of the Shortest Stories. Nueva York: Bantam Books.

Hutcheon, Linda (1984). Narcissistic Narrative: The Metafictional Paradox. Nueva York / Londres: Methuen.

Lagmanovich, David (2006). El microrrelato. Teoría e historia. Palencia: Menoscuarto.

Lejeune, Phillippe (1996). El pacto autobiográfico y otros estudios. Madrid: Megazul-Endymion.

Martínez, José Enrique (2010). "El poeta que canta y cuenta y el narrador de historias", in Voces del Noroeste, ed. José Enrique Martínez. León: Eolas, 111-158. 
Martínez García, Francisco (1982). "Antonio Pereira", in Historia de la Literatura Leonesa. León: Everest, 997-1017.

Merino, José María (2012). Cuento popular y cuento literario. León: Universidad de León / Fundación Pereira.

Mora, Gabriela (1983). En torno al cuento: de la teoría general y de su práctica en Hispanoamérica. Buenos Aires: Danilo Vergar.

Mora, Carmen de (2012). "El microrrelato intercalado y la metaficción en Respiración artificial y Nocturno de Chile", in Las fronteras del microrrelato. Teoría crítica del microrrelato español e hispanoamericano, ed. Ana Calvo Revilla y Javier de Navascués. Madrid/Frankfurt: Iberoamericana/Vervuert, 193-206.

Navascués, Javier de (2019). "Minificción digital y escritura autobiográfica: del diario al blog", in Epifanías de la brevedad. Microformas literarias y artísticas en la red, ed. Ana Calvo Revilla. Madrid: Visor, 231-249.

Pereira, Antonio (1964). El regreso. Madrid: Adonais.

Pereira, Antonio (1966). Del monte y los caminos. Barcelona: El Bardo.

Pereira, Antonio (1967). Una ventana en la carretera. Barcelona: Rocas.

Pereira, Antonio (1969). Cancionero de Segres. Madrid: Oriens.

Pereira, Antonio (1972). Dibujo de figura. Barcelona: El Bardo.

Pereira, Antonio (1976). El ingeniero Balboa y otras historias civiles. Madrid: Magisterio Español.

Pereira, Antonio (1978). Historias veniales de amor. Barcelona: Plaza \& Janés.

Pereira, Antonio (1982). Los brazos de la i griega. Gijón: Noega.

Pereira, Antonio (1985). Reseñas y confidencias. Breviarios de la calle del pez. León: Diputación de León.

Pereira, Antonio (1988). El síndrome de Estocolmo. Barcelona: Mondadori.

Pereira, Antonio (1989). Cuentos para lectores cómplices. Madrid: Espasa Calpe.

Pereira, Antonio (1991a). Relatos de andar el mundo. Madrid: Biblioteca del periódico El Sol.

Pereira, Antonio (1991b). Picassos en el desván. Barcelona: Mondadori.

Pereira, Antonio (1994). Las ciudades de Poniente. Madrid: Anaya \& Mario Muchnik.

Pereira, Antonio (1995). "Reflexiones de un escritor de cuentos", in Actas del Congreso Internacional de escritores castellano-leoneses, hispanoamericanos y portugueses, ed. Gonzalo Santoja. Valladolid: Sociedad V centenario del Tratado de Tordesillas, 167-170.

Pereira, Antonio (1997). Crónicas de Villafranca. León: Diputación de León.

Pereira, Antonio (1998). "Confesiones del autor", in Relatos sin fronteras. Junta de Castilla y León / Consejería de Educación y Cultura, 7-9.

Pereira, Antonio (1999a). Me gusta contar. Barcelona: Mario Muchnik.

Pereira, Antonio (1999b). "Cuento de los dos narradores", in Cuentos del Medio Siglo. Barcelona: Espasa Calpe, 9-10.

Pereira, Antonio (2000). Cuentos de la Cábila. León: Edilesa.

Pereira, Antonio (2006). Meteoros. Poesía, 1962-2006. Madrid: Calambur.

Pereira, Antonio (2007). La divisa en la torre. Madrid: Alianza.

Pereira, Antonio (2012). Todos los cuentos. Prólogo de Antonio Gamoneda. Madrid: Siruela. 
Pereira, Antonio (2019). Oficio de mirar. Andanzas de un cuentista, 1970-2000. Madrid: Pre-Textos.

Pratt, M. Louise (1981). "The Short Story: The Long and the Short of it", Poetics, 10.3/3: 175-194.

Quiroga, Horacio (1970). Obras inéditas y desconocidas: sobre literatura. Montevideo: Arca.

Romera Castillo, José, y Francisco Gutiérrez Carbajo (eds.) (2001). El cuento en la década de los noventa. Madrid: Visor.

Rosell, María (2009). "Autobiografías mínimas: la invención del yo en una página", in Narrativas de la postmodernidad. Del cuento al microrrelato, ed. Salvador Montesa. Málaga: Aedile, 471-482.

Rubio, David (2017). "La faceta periodística de Antonio Pereira", Siglo XXI, Literatura y cultura españolas, 17:1-11.

San Vicente, Ricardo (2018). "Relatos, de Anton Chéjov", in La literatura admirable. De Génesis a Lolita, ed. Jordi Llovet. Barcelona: Pasado \& Presente, 472-481.

Sanz, Ignacio (2012). "Todos los cuentos, Antonio Pereira", Blog La tormenta en un vaso. <http://latormentaenunvaso.blogspot.com/2012/11/todos-los-cuentos-antoniopereira.html> (17 de enero de 2020).

Sanz Villanueva, Santos (2001). "Relato y biografía", Revista de Libros, 52: 44.

Varga Llamazares, Raquel de la (2018). "La ficción hiperbreve de Antonio Pereira", Microtextualidades. Revista Internacional de microrrelato y minificción, 5: 106-115.

Vargas Llosa, Mario (2004). "Prologo", in Julio Cortázar. Cuentos completos/1 (1945-1966). Madrid: Alfaguara, 3-26.

Waugh, Patricia (1984). Metafiction: the theory and practice of self-conscious fiction. Londres / Nueva York: Methuen. 